\title{
Evaluation of Two Insect Growth Regulators (IGRS) As a Feed- Through Treatments against Adults of Culex pipiens $\mathrm{L}$. mosquito
}

\author{
Hossam EL-Din M.Zahran
}

\begin{abstract}
This study was carried out to evaluate the biological effects of two IGRs (Match ${ }^{\circledR}$ and Baycidal ${ }^{\circledR}$ ) on Culex pipiens mosquitoes when fed the adults on sugar solution mixed with $0.1,0.5$ and 1 ppm of each compound. Some delayed effects of these treatments were also determined. The results indicated that the use of each of the tested IGRs caused a reduction in the blood-feeding activity of mosquito female when compared with the controls. The reductions were 18.2, 22.7 and $31.8 \%$ by using Match and 25, 27.3 and $36.3 \%$ by using Baycidal $^{\circledR}$, respectively, at the tested concentrations. The reduction in biting activity of mosquito females may lead to a decrease in the number of fully engorged females and accordingly affect their reproductive capacity of mosquitoes. The use of Match $^{\circledR}$ and Baycidal ${ }^{\circledR}$ at the tested concentrations caused a marked prolongation in the time needed for blood meal digestion by $C$. pipiens females. The prolongation percentages were $44.4,48,8$ and $55.5 \%$ by using Match and 51.1, 55.5 and $62.2 \%$ by using Baycidal $^{\circledR}$, respectively. Also, treatments caused a reduction in the reproductive capacity. The maximum decreasing in egg production was $30.3 \%$ at concentration of $1 \mathrm{ppm}$ of Match $^{\circledR}$. The result showed that the treatment by Baycidal $^{\circledR}$ at $0.1,0.5$ and $1 \mathrm{ppm}$ led to a remarkable reduction in the egg production by $61.9,66.1$ and $69.2 \%$, respectively and also the hatchability was reduced in the treated females. Subsequent study was carried out to investigate the delayed effect of IGRs Match $^{\circledR}$ and Baycidal ${ }^{\circledR}$ on the hatched larvae. The result showed that the larval development was gradually inhibited by 17.8, 49.8 and 92.7\% by using Match $^{\circledR}$ at $0.1,0.5$ and 1 ppm, respectively. On the other hand the larval development was completely inhibited after the treatment of adults fed by 0.5 and 1 ppm Baycidal $^{\circledR}$. The larvae developed till the $2^{\text {nd }}$ instar but completely failed in molting to the $3^{\text {rd }}$ instar. Subsequent study was conduced on the effect of Match $^{\circledR}$ and Baycidal ${ }^{\circledR}$ on the longevity of the survived mosquito adults that, the records showed that no significant differences in the mean of adult longevity between treatments and control.
\end{abstract}

\section{INTRODUCTION}

Female mosquitoes are transmitters for many infectious diseases thus, their control is urgently needed. The harmful effects of conventional insecticides beside the development of resistant strains call the mosquito control specialists for searching about an effective and safe control agents. Between these agents, insect growth regulators (IGRs) which have high levels of activity and efficacy against various species of mosquitoes in a variety of habitats (Mulla et al., 1989), since IGRs could alter adult emergence, reproduction and ecdysteroid production in surviving females (Fournet et al., 1995). IGRs are suitable candidate larvicides for mosquito control due to their greater margin of safety for nontarget biota (Mulla et al., 1986). On the basis of these attributes,IGRs are likely to provide additional tools for mosquito control, supplementing microbial, pyrethroids and organophosphorus larvicides (Mulla et al., 1989).

More attention has been directed to the use of IGRs as a feed-through treatment for controlling different species of dipterous flies (Huybrechts and DeLoof, 1981; Pochon and Casida, 1983; Friedel and McDonell, 1985). In this concern, the present study was conducted to evaluate the biological effects of two IGRs $\left(\right.$ Match $^{\circledR}$ and Baycidal $^{\circledR}$ ) on Culex pipiens mosquitoes as a feedthrough treatment against the adults. The possible effects on feeding activity, time of blood meal digestion and reproductive potential of mosquitoes were investigated. The delayed effects of the above IGRs on subsequent larval development and longevity of mosquito adult survivors were also considered.

\section{MATERIALS AND METHODS}

Compounds used:

Triflumuron (TFM) (Baycidal $^{\circledR} \quad 48 \% \quad$ EC); benzoylphenylurea, 1- (2- chlorobenzoyl) -3- (4trifluoromethoxyphenyl) urea, was supplied by Bayer AG (Germany). Lufenuron (LUF) $\left(\right.$ Match $^{\circledR}$ 5\% EC); benzoylurea, (RS) -1- [2,5- dichloro-4- $(1,1,2,3,3,3,-$ hexafluoropropoxy) phenyl) -3- (2,6-difluorobenzoyl] urea was supplied by Syngenta.

Insects:

A Culex pipiens L. (Diptera: Culicidae) colony maintained in the laboratory of Medical and Veterinary Insects, Department of Applied Entomology Faculty of Agriculture, Alexandria University, for more than 10 years was used. Mosquitoes were held at $27 \pm 1{ }^{\circ} \mathrm{C}$, $70 \pm 5 \% \mathrm{RH}$, and a photo regime of 14:10 hr (light:dark) Adults were provided with a $10 \%$ sucrose solution as food source. A pigeon was introduced twice a week to the adults for blood feeding. Larvae were reared in dechlorinated water under the same and conditions and were fed daily with baby fish food.

${ }^{1}$ Department of Entomology Faculty of Agriculture (El- Shatby)

Alexandria University, Egypt

Received December 2010, Accepted December 25, 2010. 


\section{Experimental tests:}

Match $^{\circledR}$ or Baycidal ${ }^{\circledR}$ was included in $10 \%$ sugar solution at concentrations of $0.1,0.5$ and $1.0 \mathrm{ppm}$. For each concentration, the newly emerged mosquito adults from batches of 200 two days old pupae were confined in cages provided with a source of water, They were allowed to feed on treated sugar solutions soaked on cotton pads in small vials for $48 \mathrm{hrs}$. Untreated sugar solutions were served as controls. Each concentration was replicated four times. Four days post-treatment, mosquito females a pigeon was subjected to mosquito females as a source of the blood meal. The percentage of biting (the number of blood-fed females/total number of tested females $\times 100$ ) was estimated after $2 \mathrm{hrs}$. Then, each engorged female was kept with a male in a small plastic cup $(10 \mathrm{~cm}$ in diameter and $15 \mathrm{~cm}$ in height), halffilled with tap water and covered with muslin cloth. The reproductive potential of mosquito females (based on egg production and hatchability of eggs) and the time of blood digestion (the period between feeding and oviposition) were recorded for the $1^{\text {st }}$ gonotrophic cycle.

The effect of the tested IGRs on the progeny resulting from the treated females was determined by monitoring larval development from hatching to adult emergence. Four hundred first instar larvae from each concentration were randomly selected and placed into white enamel bowls (4 replicates, 100 larvae each) containing fresh tap water and given the usual larval food. Data on larval mortality, pupation and adult emergence were recorded daily, and compared with control trials. Adult longevities were also estimated for the mosquito survivors. All data were evaluated by a general linear model procedure comparing least square means using a SAS computer program.

\section{RESULTS AND DISCUSSION}

Effects of the Match $^{\circledR}$ and Baycidal $^{\circledR}$ on some behavioral and biological aspects of $C$. pipiens when fed as adult mosquitoes via the sugar solution have been evaluated. The results showed that the use of Match ${ }^{\circledR}$ and Baycidal $^{\circledR}$ as feed-through trials against $C$. pipiens at concentrations of $0.1,0.5$ and $1 \mathrm{ppm}$ for each compound caused a reduction in the blood-feeding activity of mosquito females (Table 1). At the tested concentrations $(0.1,0.5$ and $1 \mathrm{ppm})$, the feeding activity of mosquito females was reduced by about $18.2,22.7$ and $31.8 \%$ in the case of Match ${ }^{\circledR}$ treatments and 25, 27.3 and 36.3\% in the case of Baycidal $^{\circledR}$, respectively, compared with the control. These results are in accordance with Saleh and Wright (1990). They conducted similar trials using cyromazine $(0.5-25 \mathrm{ppm})$ as a feed through treatment against $C$. pipiens and Ae. epacticus. Also, feeding activity was significantly reduced in An. dirus by about $10 \%$ and $25 \%$ after exposure to 0.01 and $0.1 \mathrm{ppb}$ of the IGRs methoprene (Sithiprasasna et al. 1996).

Generally, the initiation of biting behavior is mediated by juvenile hormone in C. pipiens (Meola and Petralia, 1980). Therefore, compounds with anti-juvenile hormone activity would presumably be highly effective in preventing blood feeding by blocking juvenile hormone release or its action in adult female mosquitoes. However, the reduction in biting activity of mosquito females may lead to a decrease in the number of fully engorged females and accordingly affect the reproductive capacity of mosquitoes.

Results in Table (2) showed that the times of blood digestion $\left(2^{\text {nd }}\right.$ phase of gonotrophic cycle) in mosquito females of C.pipiens treated by the tested concentrations of Match $^{\circledR}$ were 6.5, 6.7 and 7.0 days, respectively. These times were $6.8,7.0$ and 7.3 days when mosquito females were treated by the tested concentrations of Baycidal $^{\circledR}$, respectively. In the control, this time was 4.5 days. Therefore, treatment with Match ${ }^{\circledR}$ and Baycidal ${ }^{\circledR}$ as a feed-through treatment caused a significant

Table1. The effect of Match and Baycidal as a feed-through treatment on the blood-feeding activity in $C$. pipiens mosquitoes

\begin{tabular}{cccccccc}
\hline IGRs & Match & & & Baycidal & Control \\
\hline Conc.(ppm) & $\mathbf{0 . 1}$ & $\mathbf{0 . 5}$ & $\mathbf{1 . 0}$ & $\mathbf{0 . 1}$ & $\mathbf{0 . 5}$ & $\mathbf{1 . 0}$ & - \\
\hline $\begin{array}{c}\text { No.of engorged } \\
\text { females* }\end{array}$ & 36 & 34 & 30 & 33 & 32 & 28 & 44 \\
\hline $\begin{array}{c}\text { Feeding activity } \\
\text { (FA) \% }\end{array}$ & 72 & 68 & 60 & 66 & 64 & 56 & 88 \\
\hline Reduction (R)\% & 18.2 & 22.7 & 31.8 & 25 & 27.3 & 36.3 & $-^{-}$ \\
\hline
\end{tabular}

\footnotetext{
* 50 mosquito females were used. $\quad$ - No data 
prolongation in the time needed for blood meal digestion by about $44.4,48.8$ and $55.5 \%$ in case of Match $^{\circledR}$ and 51.1, 55.5 and $62.2 \%$ in the case of Baycidal $^{\circledR}$, respectively. These results are in parallel with other investigations using six JH-like activity compounds (Kelada et al, 1980) and Bacillus thuringiensis H-14 (Saleh et al.1990; Saleh and Wright, 1990 ) against $C$. pipiens mosquitoes. They stated that a marked prolongation in the time needed for blood meal digestion ingested by mosquito females. However, such a study is useful for the estimation of the frequency of mosquito contact with the host. For instance, if the gonotrophic cycle is 4 or 5 days it means that the mosquito will feed on average every 4 or 5 days; this has an important effect on the transmission of the disease. Therefore, determination of the time of gonotrophic cycle is one of the necessary parameters for the calculation of vectorial capacity (WHO, 1975).

The effect of Match $^{\circledR}$ and Baycidal $^{\circledR}$ on the reproductive potential of $C$. pipiens when fed to adult mosquitoes in the sugar solution is summarized in Table (3).Results showed that Match $^{\circledR}$ treatments at concentrations of 0.1 and $0.5 \mathrm{ppm}$ had no effect on egg production by mosquito females. A maximum reduction in fecundity $(30.3 \%)$ was observed in mosquito females received sugar solution containing $1 \mathrm{ppm}$ of Match $^{\circledR}$. On the other hand, results indicated that Baycidal $^{\circledR}$ treatments at concentrations of $0.1,0.5$ and $1 \mathrm{ppm}$ led to a marked reduction in egg-laying capacity of $C$. pipiens mosquitoes. The mean numbers of eggs were 52.1, 46.4 and $42.1 /$ female, while, it was 136.9 / female in control (Table 3). Therefore, the reduction percentages in the fecundity of female were $61.9 \%, 66.1 \%$ and $69.2 \%$ at the tested concentrations, respectively.

Data on the hatchability of eggs are shown in Table (3). The percentages of egg hatching were 92.3, 86.3, and $85.3 \%$ in mosquito adults that fed $\operatorname{Match}^{\circledR}$ at concentrations of $0.1,0.5$ and $1.0 \mathrm{ppm}$ in the sugar solution. Statistical analysis showed that the difference in the hatchability of eggs between the treatment groups and the control $(89.7 \%)$ was insignificant. On the other hand, the records showed that the percentages of egg hatching were $55.5,46.9$ and $47.9 \%$ in mosquito adults that fed Baycidal $^{\circledR}$ at doses of $0.1,0.5$ and $1.0 \mathrm{ppm}$, respectively, when compared with the control. This means that Baycidal ${ }^{\circledR}$ as a feed-through treatment at the tested concentrations caused 34.2, 42.8 and $41.8 \%$ reduction in the hatchability of eggs.

It has been reported in the literature that egg hatching is strongly inhibited, in Drosophila melanogaster females after feeding on a diet containing lufenuron, the percentage of hatching of eggs laid by lufenuron-treated females was insignificant compared to that of untreated females. (Wilson and Cryan, 1997).Similar results were observed following exposure of Tribolium castaneum to novaluron (Kostyukovsky and Trostanetsky, 2006).

Our results are in accordance with Saleh and Wright (1990). They used cyromazine against $C$. pipiens and Ae. epacticus and they mentioned that cyromoazine treatments led to a reduction in the egg-laying capacity. Most studies described tests of Baycidal ${ }^{\circledR}$ against different species of dipterous flies. Friedel and McDonell (1985) mentioned that the egg production was decreased and the hatching of eggs remained unaffected in the sheep blow fly Lucilia cuprina fed on cyromazine $(1-20 \mathrm{ppm})$ in the drinking water. A concentration of up to $100 \mathrm{ppm}$ cyromazine in the drinking water did not affect egg-laying capacity in Musca domestica (Pochon and Casida, 1983). Generally, it has been suggested that treatment with the test IGRs as feed-through trials may affect the ovaries (e.g., the germarium) or vitellogenesis and consequently the fecundity of mosquito females (Huybrechts and DeLoof, 1981). However, the present study suggests that the present IGRs particularly Baycidal ${ }^{\circledR}$ will also prove to have a significant effect on the reproductive potential of other dipteran species that

Table 2. The effect of Match and Baycidal as a feed-through treatment on the time of blood digestion ( $2^{\text {nd }}$ phase of gonotrophic cycle) in C. pipiens mosquitoes

\begin{tabular}{|c|c|c|c|c|c|c|c|c|}
\hline \multirow{2}{*}{\multicolumn{2}{|c|}{$\begin{array}{c}\text { IGRs } \\
\text { Conc. (ppm) }\end{array}$}} & \multicolumn{3}{|c|}{ Match } & \multicolumn{3}{|c|}{ Baycidal } & \multirow{2}{*}{$\begin{array}{c}\text { Control } \\
-\end{array}$} \\
\hline & & 0.1 & 0.5 & 1.0 & 0.1 & 0.5 & 1.0 & \\
\hline \multirow{3}{*}{$\begin{array}{l}\text { Digestio } \\
\text { n time } \\
\text { (in days) }\end{array}$} & Range & $4-8$ & $4-11$ & $4-11$ & $4-10$ & 4-10 & $5-11$ & $4-6$ \\
\hline & Average* \pm S.E. & $\begin{array}{c}6.5^{\mathrm{b}} \pm \\
0.28\end{array}$ & $\begin{array}{l}6.7^{\mathrm{b}} \pm \\
0.36\end{array}$ & $\begin{array}{l}7.0^{b} \pm \\
0.44\end{array}$ & $6.8^{b} \pm 0.34$ & $\begin{array}{l}7.0^{b} \pm \\
0.45\end{array}$ & $\begin{array}{l}7.3^{b} \pm \\
0.15\end{array}$ & $4.5^{\mathrm{a}} \pm 0.19$ \\
\hline & $\begin{array}{c}\text { Increase in time } \\
\text { of blood } \\
\text { digestion }(\%)\end{array}$ & 44.4 & 48.8 & 55.5 & 51.1 & 55.5 & 62.2 & - \\
\hline
\end{tabular}


Table 3. The effect of Match and Baycidal as a feed-through treatment on the reproductive potential of $C$. pipiens mosquitoes

\begin{tabular}{|c|c|c|c|c|c|c|c|}
\hline IGRs & & Match & & & Baycidal & & Control \\
\hline Conc. (ppm) & 0.1 & 0.5 & 1.0 & 0.1 & 0.5 & 1.0 & - \\
\hline Total No. of eggs & 2597 & 2467 & 1939 & 1055 & 945 & 876 & 2702 \\
\hline $\begin{array}{c}\text { Mean No. of egg } \\
\text { female }\end{array}$ & $\begin{array}{c}128.4^{\mathrm{a}} \pm \\
1.10\end{array}$ & $\begin{array}{c}121.6^{\mathrm{a}} \pm \\
1.7\end{array}$ & $95.3^{\mathrm{b}} \pm 1.1$ & $\begin{array}{l}52.1^{\mathrm{c}} \pm \\
2.12^{-} \\
\end{array}$ & $46.4^{c} \pm 1.6$ & $\begin{array}{l}42.1^{\mathrm{c}} \pm \\
0.41\end{array}$ & $\begin{array}{c}136.9^{\mathrm{a}} \pm \\
2.15\end{array}$ \\
\hline $\begin{array}{l}\text { (\%) fecundity } \\
\text { reduction }\end{array}$ & 6.2 & 11.2 & 30.3 & 61.9 & 66.1 & 69.2 & - \\
\hline $\begin{array}{l}\text { Total No. of } \\
\text { hatched eggs }\end{array}$ & 2396 & 2129 & 1655 & 586 & 443 & 420 & 2425 \\
\hline Hatchability (\%) & 92.3 & 86.3 & 85.3 & 55.5 & 46.9 & 47.9 & 89.7 \\
\hline $\begin{array}{c}\text { Effect on } \\
\text { hatchability (\%) }\end{array}$ & +2.6 & -3.4 & -4.4 & -34.2 & -42.8 & -41.8 & - \\
\hline
\end{tabular}

Numbers with the same letter are not significantly different at 0.05 level require a blood meal for the initiation and completion of vitellogenesis. Mansur et al. (2010) explained the reduction of number of chorionated oocytes, the reduction of eggs laid and the reduction in the viability of the eggs of Rhodnius prolixus after exposure to lufenuron $\left(\mathrm{Match}^{\circledR}\right)$ as a consequence of osorption following inhibition of chitin synthesis and/or cuticle assembly.

Subsequent studies were also conducted to investigate the possible delayed effect of Match $^{\circledR}$ and Baycidal ${ }^{\circledR}$ on the development of $C$. pipiens larvae when fed to adult mosquitoes (Table 4). Although Match ${ }^{\circledR}$ had no apparent effect on egg hatch (Table 3), subsequent larval development was inhibited progressively as the concentrations of Match $^{\circledR}$ increased. At concentrations of $0.1,0.5$ and $1.0 \mathrm{ppm}$, most larvae that formed apparently normal pupae often died before the adult emergence and accordingly, 17.8, 49.2 and $92.7 \%$ inhibition of adult formation was occurred. However, this decline in the survival rates may indicate that some

of delayed fetal effects of Match ${ }^{\circledR}$ occurred during the development from larvae to pupae, and accordingly, the resulting pupae and emerging mosquito adults were affected. On the other hand, the results indicated that the larval development of $C$. pipiens was completely inhibited when adult mosquitoes fed Baycidal $^{\circledR}$ at the dosage of 0.5 and $1.0 \mathrm{ppm}$ (Table 4). Results showed that most hatched larvae were fed and developed normally for the duration of the $2^{\text {nd }}$ instar, but failed to molt completely to the $3^{\text {rd }}$ larval instar. However, it can be suggested that the difference in the trend of inhibitory effect of Match ${ }^{\circledR}$ and Baycidal $^{\circledR}$ on the subsequent larval development of $C$. pipiens may be due to a special mechanism of the tested compounds. The obtained findings are in agreement with a previous study (Kawada et al., 2003) that discussed the larvicidal efficacy of IGR Match $^{\circledR}$ on anopheline mosquito (A. sergenti, gambiae and albimanus).

Table (4) shows the delayed effect of Match ${ }^{\circledR}$ and Baycidal $^{\circledR}$ as a feed-through treatment on the longevity

Table 4. The effect of Match and Baycidal as a feed- through treatment on subsequent larval development and the longevity of adult survivors of $C$. pipiens mosquitoes

\begin{tabular}{|c|c|c|c|c|c|c|c|}
\hline \multirow{3}{*}{$\begin{array}{c}\text { IGR } \\
\text { (ppm) }\end{array}$} & \multirow{3}{*}{$\begin{array}{l}\text { No. of } \\
\text { Dead- } \\
\text { larvae }^{\text {a }}\end{array}$} & \multirow{3}{*}{$\begin{array}{c}\text { No. of } \\
\text { pupae } \\
\text { produced }\end{array}$} & \multicolumn{3}{|c|}{ Adult emerge } & \multicolumn{2}{|c|}{$\frac{\text { Adult longevity }^{c}}{\text { (in days) } \pm \text { S.E. }}$} \\
\hline & & & \multirow{2}{*}{$\underline{\text { Total }}$} & \multicolumn{2}{|c|}{ Inhibition $^{b}$} & \multirow{2}{*}{$\underline{\text { Males }}$} & \multirow{2}{*}{ Females } \\
\hline & & & & Obs. & Cor. & & \\
\hline \multicolumn{8}{|l|}{ Match } \\
\hline 0.1 & 50 & 350 & 301 & 24.7 & 17.8 & $17.99 \pm 0.78$ & $28.01 \pm 0.90$ \\
\hline 0.5 & 147 & 253 & 187 & 53.2 & 49.2 & $15.3 \pm 0.87$ & $31.0 \pm 0.76$ \\
\hline $\mathbf{1 . 0}$ & 192 & 208 & 18 & 95.5 & 92.7 & $18.3 \pm 0.82$ & $23.9 \pm 0.89$ \\
\hline \multicolumn{8}{|l|}{ Baycidal } \\
\hline 0.1 & 246 & 154 & 86 & 78.5 & 76.7 & $18.9 \pm 0.81$ & $26.7 \pm 0.94$ \\
\hline 0.5 & 365 & 35 & 0.0 & 100 & 100 & - & - \\
\hline 1.0 & 400 & 0.0 & 0.0 & 100 & 100 & - & - \\
\hline Control & 21 & 378 & 368 & 8 & 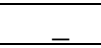 & $7.4 \pm 0.83$ & $27.5 \pm 0.90$ \\
\hline
\end{tabular}


of mosquito adults that survived from the above hatched larvae. In general, the records showed that mosquito females of both treated and untreated groups live much longer than the males.

Finally, it can be concluded that mosquito females that fed on (in water) treated surfaces with Match $^{\circledR}$ or Baycidal $^{\circledR}$ are likely not only lay fewer eggs, but also lay eggs that will ultimately produce fewer (or no) adults, even if the mosquito larvae do not come in contact with these compounds.

\section{REFERENCES}

Fournet, F.; C. Sannier; M. Moriniere; P. Porcheron and N. Monteny (1995). Effect of two insect growth regulators on ecdysteroid production in Aedes egypti. J. Med. Entomol. 32:588-593.

Friedel, T. and P.A.McDonell ( 1985 ). Cyromazine inhibits reproduction and larval development of the Australian sheep blow fly ( Diptera : Calliphoridae). J. Econ. Ent. 78:868 -873.

Huybrechts, R. and A. Deloof (1981). Effect of ecdysterone on vitellogenin concentration in haemolymph of male and female Sarcophaga bullata.Int. J. Invertebr. Report 3: 157- 168.

Kawada, H.; Y. Shano,; T. Ito and Y. Abo (2003). Laboratory evaluation of insect growth regulators against several of Anopheline mosquitoes. Jap. J. Santi. Zool. 44(4): 349353.

Kelada, N.L.; I.A. Gaaboub and I.A. Rawash (1980). A comparison of the juvenalizing effect of six juvenile hormone-like activity compounds on Egyptian Culex pipiens. J. Agric. Sci. Camb. 95, 203-212.

Kostyukovsky, M. and A. Trostanetsky (2006). The effect of a new chitin synthesis inhibitor, novaluron, on various developmental stages of Tribolium castaneum (Herbst). J. Stored Prod. Res, 42: 136-148.

Mansur, J.F.; J. Figueira-Mansur; A. S. Santos; H. Santosjunior; I.B. Ramos; M. N.D. Medeiros; E.A.Medeiros; E.A. Machado; C.R.Kaiser; S. Muthkrishnan; H. Masuda; A.M.H. Vansconcellos; A.C.A. Melo and M. F. Moreira (2010). The effect of lufenuron, a chitin synthesis inhibitor, on oogenesis of Rhodnius prolixus. Pesticide Biochemistry and physiology 98: 59-67.
Meola, R.W. and R.S. Petralia (1980). Juvenile horomone induction of biting activity in Culex mosquitoes. Science 209: 1548-1550.

Mulla, M.S.; A.H. Darwazeh; B. Kennedy and D.M. Dawson (1986). Evaluation of new insect growth regulators against mosquitoes with notes on nontarget organisms. J. Am. Mosq. Control Assoc., 2(3): 314-320.

Mulla, M.S.; A.H. Darwazeh and T.E. Schreiber (1989). Impact of new insect growth regulators and their formulations on mosquito larval development in impoundment and floodwater habitats. J.Am. Mosq. Cont. Assoc. 5: 15-20.

Pochon. J.M. and J.E. Casida (1983). Cyromazine sensitive stages of housefly development : influence of penetration , metabolism and persistency on potency. Ent. Exp. Appl. 34 $: 251-256$.

Saleh, M.S. and R.E. Wright (1990). Evaluation of the IGRs cyromazine as a feed-through treatment against Culex pipiens and Aedes epacticus (Diptera, Culicidae).J.App.Ent.109,247-250.

Saleh, M.S.; N.L.Kelada and M.I.Abdeen (1990). The delayed effects of Bacillus thuringiensis $\mathrm{H}-14$ on the reproductive potential and subsequent larval development of the mosquito Culex pipiens L. J. Appl. Ent. 109: 520523.

Sithiprasasna, R.; E. Luepromchai and K.J. Linthicum (1996). Effects of sublethal dosages of methoprene on Anopheles dirus species A and B. J. Am. Mosq. Control Assoc., 12(13), 1: 483-486.

Wilson, T.G. and J.R. Cryan (1997). Lufenuron, a chitinsynthesis inhibitor, interrupts development of Drosophila melanogaster. J. Exp. Zool. 278: 37-44.

\section{Anonymous}

SAS (Statistical analysis system), (1986). SAS users guide statistics SAS institute, cary, North Carolina, U.S.A.

World Health Organization (1975). Manual on practical Entomology in malaria. Part II (Meth.\& Tech.) Geneva, Swizerland. 


\section{الملخص العربي}

\section{تقييم نوعين من منظمات نمو الحشرات "كمعاملات من خلال التغذية" ضد الحشرات الكاملة}

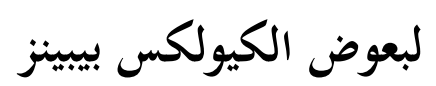

حسام الدين مجدي زهران

هذه المركبات فن المحلول السكرى. لوحظ أقصى إنخفاض فن إنتاج البيض

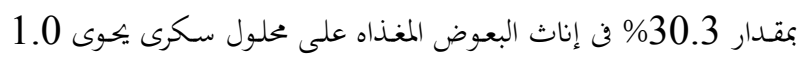

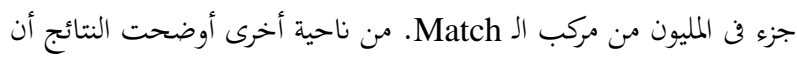

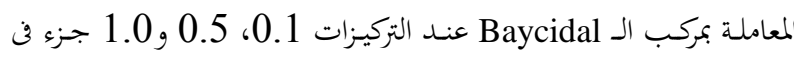
المليون قد أدت إلى إنخفاض واضح في قدرة الإناث على وضع البيض بمقدار 61.9، 66.1 و69.2\% على الترتيب و ذلك عند المقارنة بالكنترول. كما إنخفضت أيضاً نسبة فقس البيض الناتج عن تلك الحس الحشرات المعاملة.

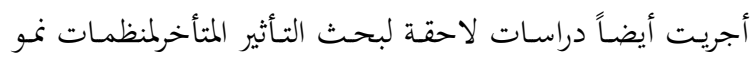

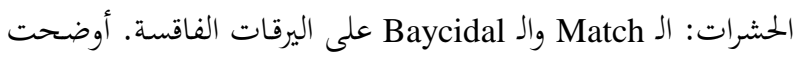

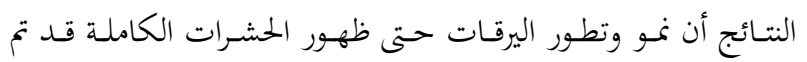

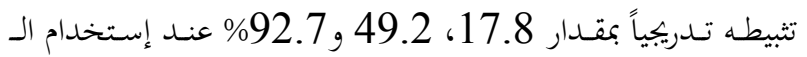
Match بالتركيزات 0.1، 0.5 و1.0 جزء في المليون على الترتيب. من ناحية أخرى أكدت النتائج أن نمو اليرقات وتطورها حتى ظهور

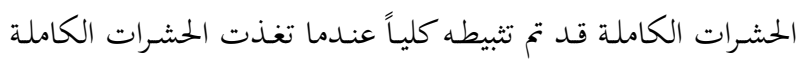

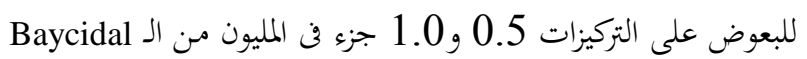

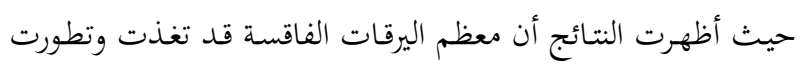

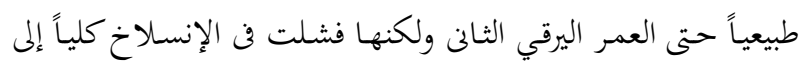

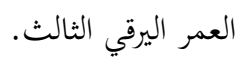
كمـا تم دراسة تأثير الـ Match والـ Baycidal على طول عمر

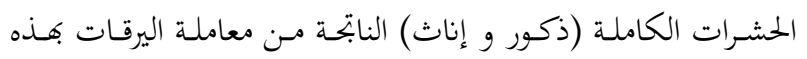

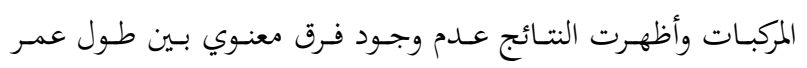
الحشرات الكاملة النابتحة من اليرقات المعاملة و الكنترول.
أجريت هذه الدراسة لتقييم التأثير الحيوي لنوعين من منظمات نمو

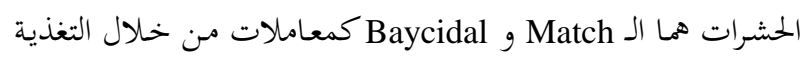

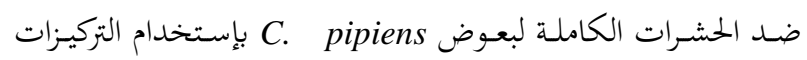
0.1، 0.5 و1.0 جزء في المليون لكل مركب. أوضحت النتائج أن

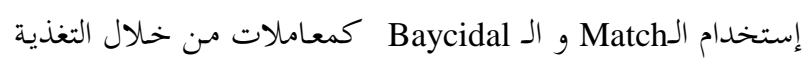

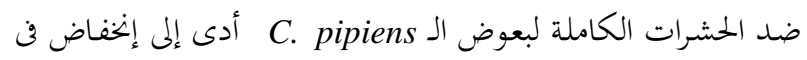

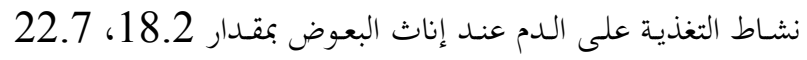

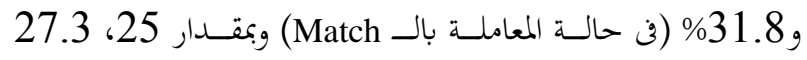

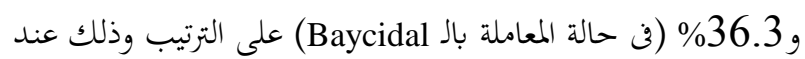

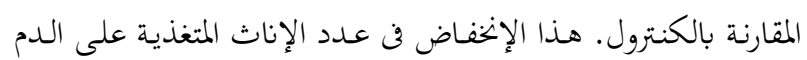
يؤثر بالتالى على الكفاءة التناسلية للبعوض.

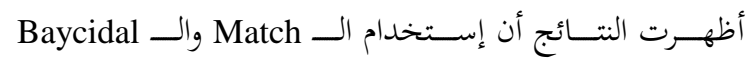
كمعاملات من خلال التغذية بالتركيزات المستخدمة قد سبب إطالة

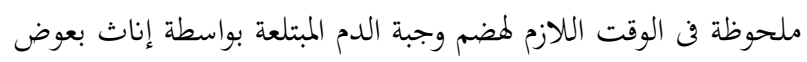
C. Pipiens

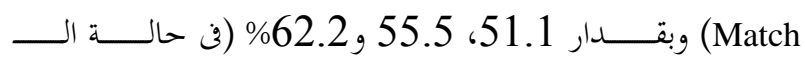

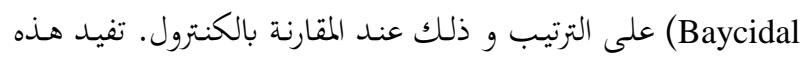

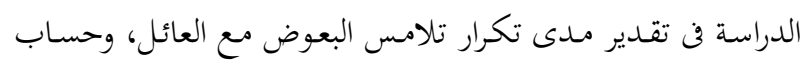

$$
\text { مقدرته كناقل للمسببات المرضية. }
$$

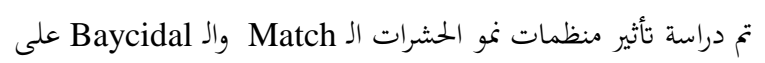

$$
\text { القدرة التناسلية لبعوض ماسئ منظ المتغذى على C. pipiens }
$$

